\title{
Let's Talk about Digital Learners in the Digital Era
}

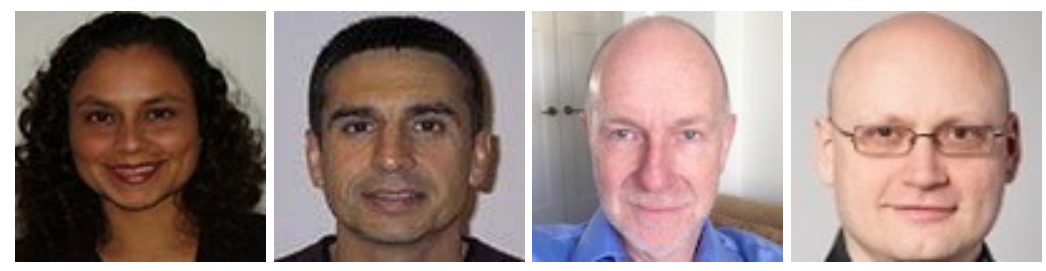

Eliana Esther Gallardo-Echenique ${ }^{1}$, Luis Marqués-Molías ${ }^{1}$, Mark Bullen², and Jan-Willem Strijbos ${ }^{3}$ ${ }^{1}$ Rovira i Virgili University, Spain, ${ }^{2}$ University of British Columbia, Canada, ${ }^{3}$ Ludwig-Maximilians-University of Munich, Germany

\begin{abstract}
This paper reports on a literature review of the concept of "Digital Natives" and related terms. More specifically, it reports on the idea of a homogeneous generation of prolific and skilled users of digital technology born between 1980 and 1994. In all, 127 articles published between 1991 and 2014 were reviewed. On the basis of the findings, there appears to be no commonly-accepted definition of a "Digital Native". The concept varies among individuals, societies, regions and nations, and also over time. Moreover, there are a number of variables other than age that may help us understand the nature of students' use of digital technologies. The so-called "Digital Native" literature demonstrates that despite students' high digital confidence and digital skills, their digital competence may be much lower than those of their "digital teachers". Given the confusion surrounding "Digital Native" and its affiliates, we propose to unify them under the concept "digital learners".
\end{abstract}

Keywords: Digital learner; digital natives; millennials; integrative literature review; thematic analysis 


\section{Introduction}

In most developed countries students use digital technologies and the Internet in all facets of their daily life (school, work and leisure) (Kolikant, 2010; Levin \& Arafeh, 2002). Most of these students, who were born roughly between 1980 and 1994 represent the first generation to grow up with this new technology and have been characterized by their familiarity and confidence with respect to Information and Communication Technologies (ICT). They have spent most of their lives surrounded by digital communication technology. They use the Internet, text messaging, and social networking, but they are using these technologies primarily for social and entertainment purposes. According to Gibbons (2007) they communicate differently (e.g., text messaging and instant message), use a different written language (e.g., text messaging), interact and socialize differently (e.g., via avatars in online games and Facebook), and have a different sense of authorship (e.g., Flickr and personal blogs).

The "Digital Native" discourse emerged in the late 1990s and has its origins in the work of Tapscott $(1998,2009)$ and Prensky (2001a, 2001b). Until recently the notion that there is a generation of learners with distinct skills and characteristics attributable to the exposure to digital technology had been accepted uncritically by many educators. Despite the considerable attention focused on "Digital Natives", remarkably few studies carefully investigated the characteristics of this group. Moreover, the concept emerged from developed world contexts (primarily the US and Canada but also Australia, the United Kingdom, Western Europe and Japan). We know little about how relevant this is in developing world contexts where access to advanced technology is limited (Malhotra, Ahouilihoua, Eshmambetova, Kirungi, et al., 2008).

Most of the studies that were used to support the digital native concept were either methodologically suspect or relied excessively on anecdotal data. Moreover, little empirical evidence had been provided to support claims made about the "Digital Natives" and the implications for higher education (Bullen, Morgan, \& Qayyum, 2011). This changed in 2008 as researchers began to take a more critical view towards this issue and a number of methodologically sound studies were published (Bennett, Maton, \& Kervin, 2008; Bullen, Belfer, Morgan, \& Qayyum, 2009; Kennedy, Krause, Judd, Churchward, Gray, \& Krause, 2008; Lai \& Hong, 2014; Nicholas, Rowlands \& Huntington, 2007; Rapetti \& Cantoni, 2010b; Thomas, 2011). Despite this, the concept of the digital native remains ambiguous and ill-defined.

\section{Aim}

The aim of this paper is to develop a unifying concept about students in the digital era under the term "digital learners". We will first address the conceptual confusion in the literature and elaborate on terms, concepts and characteristics, leading to three distinct perspectives on students in the digital era. Subsequently arguments for our proposed unifying concept "digital learners" will be provided. The primary goal of this review is to provide educational researchers and practitioners with a clearer image of a new generation of learners with characteristics related 
to their familiarity with digital technology. Also, we want to provide a critique of past research related to the term "Digital Natives", because this perspective seems to be inappropriate or insufficient to describe the population of current learners, as well as suggest some directions for future research.

\section{Method}

To address our research aim we performed an integrative literature review as outlined by Torraco (2005), which "reviews, critiques, and synthesizes representative literature on a topic in an integrated way such that new frameworks and perspectives on the topic are generated" (Torraco, 2005, p. 356). An integrative review is a specific review method that summarizes past empirical or theoretical studies to provide a more comprehensive understanding of a particular phenomenon with the aim to find a solution to a particular problem or suggest directions for future research (Russell, 2005; Torraco, 2005; Whittemore \& Knafl, 2005). An integrated review “(...) is particularly appropriate when existing research is scattered across disparate areas and has not been systematically analysed and integrated" (Hamilton \&Torraco, 2013, p. 311).

Using Torraco's (2005) framework as a guide, the first step was the selection of relevant literature. The review spanned a wide range of empirical and theoretical research-based articles, books, journals, reports and grey literature (e.g., conference website and published proceedings) in an electronic search using various databases such as ISI Web of Knowledge, ERIC, Social Sciences Citation Index ${ }^{\circledR}$, ScienceDirect, SAGE Publications, Wiley Online Library, Taylor \& Francis Online, Emerald Group Publishing, UNESDOC Database and Google Scholar.

A focused and uniform search of each database was carried out using predetermined inclusion/ exclusion criteria (Table 1). As a starting point the following key subject terms were used in identifying exemplars: "Digital Natives", "Net Generation", "Millennials" and "Generation Y". Whenever a new term or conceptually similar word appeared during the search, it was added to the list. To conduct the most comprehensive search, reference lists of searched articles were examined for articles that may not have been found by electronic databases. An online thesaurus - available for some electronic databases - proved to be a helpful tool, as it provided a selection of related, narrower, or broader terms for our topic. The search strategy identified 2,500 potentially relevant publications. Consequently, a staged review was employed (Torraco, 2005, p. 361). In the first stage the titles and abstracts of the 2,500 identified publications were scrutinised independently by two reviewers for their relevance. In the second stage an in-depth analysis was performed on the 127 publications that met the inclusion criteria and corresponded to the aim of our review.

This work is licensed under a Creative Commons Attribution 4.0 International License. 
Table 1

Inclusion and Exclusion Criteria

Inclusion criteria

a) empirical and research-based publications;

b) qualitative, quantitative, and mixed-method research studies;

c) specialized textbooks and peer-reviewed journal articles;

d) only full-text articles;

e) reports commissioned by international organizations;

f) literature reviews (including unpublished/ grey literature: government reports, policy

statements, conference proceedings, theses, dissertations, and research reports);

g) English language only; and

h) published between J anuary 1991 and December 2014 (we purposefully selected 1991 as our starting point, as the first term to refer to students in the digital era was proposed by Howe and Strauss in 1991).

a) no access to full-text articles;

b) opinion papers; and

c) best practice reports.

Thematic analysis - clustering texts into themes and combinations of categories - was conducted to identify, organize, analyse, describe and report patterns in rich detail (Braun \& Clarke, 2006; Cohen, Manion, \& Morrison, 2007). In the final stage of the review, the literature was further sorted into major categories by determining the main contribution of each publication in relation to what is known about students in the digital era. The publications were categorized along the three views suggested by Rapetti (2012) - enthusiast, concerned ones, and critic (see Table 4 for a detailed description) - to understand how authors perceive and define learners' use of ICT. Additionally, the publications were categorized along (a) country of origin, (b) design of study, and (c) source. The categorization in Table 2 was performed by the first author and the review process and outcomes were independently checked by the second author via the audit procedure (Akkerman, Admiraal, Brekelmans, \& Oost, 2008).

\section{Terms, Concepts and Characteristics}

The literature review revealed 48 terms related to the notion of this supposedly "new generation" of students in the digital era with a high affinity and tendency to use digital technology, of which the term "Digital Natives" has been the most prominent in the past decade. Table 2 provides an overview of the wide variety of concepts/ terms derived from the literature review used to describe these students. Each approach to describing this new group of students carries with it some 
distinct features, but in general the terms are used interchangeably (J ones, Ramanau, Cross, \& Healing, 2010). According to the literature, the three most common terms in circulation are: Digital Natives, Net Generation and Millennials (J ones \& Czerniewicz, 2010; J ones et al., 2010; Rapetti \& Cantoni, 2010b; Rapetti \& Marshall, 2010), which will be explained in more detail.

Table 2

Terms Used to Characterize Students in the Digital Era

\begin{tabular}{|c|c|c|c|c|c|c|}
\hline Term & Reference & View & Design & Source & Country & Year \\
\hline \multirow{8}{*}{ Generation Y } & Howe \& Strauss* & Enthusiast & Theoretical & $\overline{\text { Book }}$ & $\overline{\mathrm{USA}}$ & 1991 \\
\hline & Lancaster \& & Enthusiast & Empirical & Book & USA & 2002 \\
\hline & Jorgensen & Critic & Theoretical & Journal & Australia & 2003 \\
\hline & $\begin{array}{l}\text { Oblinger \& } \\
\text { Oblinger }\end{array}$ & Enthusiast & Theoretical & J ournal & USA & 2005 \\
\hline & Weiler & Critic & Theoretical & Journal & USA & 2005 \\
\hline & Cantoni \& Tardini & Critic & Theoretical & Journal & Switzerland & 2010 \\
\hline & $\begin{array}{l}\text { Djamasbi, Siege \& } \\
\text { Tullis }\end{array}$ & Enthusiast & Empirical & J ournal & USA & 2010 \\
\hline & Rapetti \& Marshall & Critic & Empirical & J ournal & $\begin{array}{c}\text { Barbados/ } \\
\text { Trinidad and } \\
\text { Tobago/J amaica }\end{array}$ & 2010 \\
\hline \multirow{14}{*}{ Millennials } & Howe \& Strauss* & Enthusiast & Theoretical & Book & USA & 1991 \\
\hline & Howe \& Strauss & Enthusiast & Theoretical & Book & USA & 2000 \\
\hline & $\begin{array}{l}\text { Lancaster \& } \\
\text { Stillman }\end{array}$ & Enthusiast & Empirical & Book & USA & 2002 \\
\hline & Martin \& Tulgan & Enthusiast & Theoretical & Book & USA & 2002 \\
\hline & DeBard & Concerned & Theoretical & J ournal & USA & 2004 \\
\hline & Coomes \& DeBard & Concerned & Theoretical & J ournal & USA & 2004 \\
\hline & $\begin{array}{l}\text { McMahon \& } \\
\text { Pospisil }\end{array}$ & Enthusiast & Empirical & Conference & Australia & 2005 \\
\hline & $\begin{array}{l}\text { Oblinger \& } \\
\text { Oblinger }\end{array}$ & Enthusiast & Theoretical & J ournal & USA & 2005 \\
\hline & Downing & Enthusiast & Theoretical & J ournal & USA & 2006 \\
\hline & $\begin{array}{l}\text { Simoneaux \& } \\
\text { Stroud }\end{array}$ & Enthusiast & Empirical & J ournal & USA & 2010 \\
\hline & Taylor \& Keeter & Enthusiast & Empirical & Report & USA & 2010 \\
\hline & Bajt & Enthusiast & Theoretical & J ournal & USA & 2011 \\
\hline & $\begin{array}{l}\text { DiLullo, McGee \& } \\
\text { Kriebel }\end{array}$ & Critic & Empirical & J ournal & USA & 2011 \\
\hline & Koeller & Enthusiast & Theoretical & Journal & USA & 2012 \\
\hline Net-agers & Howe \& Strauss & Enthusiast & Theoretical & Book & USA & 1991 \\
\hline $\begin{array}{l}\text { Next Great } \\
\text { Generation }\end{array}$ & Howe \& Strauss & Enthusiast & Theoretical & Book & USA & 1991 \\
\hline \multirow{4}{*}{$\begin{array}{l}\text { Nintendo } \\
\text { generation }\end{array}$} & Soloway* & Enthusiast & Theoretical & Journal & $\overline{\text { USA }}$ & 1991 \\
\hline & $\begin{array}{l}\text { Green, Reid, \& } \\
\text { Bigum }\end{array}$ & Critic & Empirical & $\begin{array}{c}\text { Book } \\
\text { chapter }\end{array}$ & Australia & 1998 \\
\hline & Frand & Enthusiast & Theoretical & J ournal & USA & 2000 \\
\hline & Guzdial \& Soloway & Enthusiast & Empirical & J ournal & USA & 2002 \\
\hline
\end{tabular}


Let's Talk about Digital Learners in the Digital Era

Gallardo-Echenique, Marqués-Molías, Bullen, and Strijbos

\begin{tabular}{|c|c|c|c|c|c|c|}
\hline $\begin{array}{l}\text { Grasshopper } \\
\text { minds }\end{array}$ & Papert* & Enthusiast & Theoretical & Book & USA & 1993 \\
\hline Clickerati & Harel* & Enthusiast & Theoretical & Journal & USA & 1997 \\
\hline $\begin{array}{l}\text { Digital } \\
\text { generation }\end{array}$ & Tapscott & Enthusiast & Empirical & Book & $\overline{\mathrm{USA}}$ & 1998 \\
\hline \multirow{22}{*}{$\begin{array}{l}\text { Net } \\
\text { Generation }\end{array}$} & Tapscott* & Enthusiast & Empirical & Book & $\overline{\text { USA }}$ & 1998 \\
\hline & Cameron & Critic & Empirical & Conference & Australia & 2005 \\
\hline & $\begin{array}{l}\text { Oblinger \& } \\
\text { Oblinger }\end{array}$ & Enthusiast & Theoretical & J ournal & USA & 2005 \\
\hline & Gibbons & Enthusiast & Empirical & Conference & USA & 2007 \\
\hline & Kennedy et al. & Critic & Empirical & Conference & Australia & 2007 \\
\hline & Guitert et al. & Critic & Theoretical & Conference & Spain & 2008 \\
\hline & Kennedy et al. & Critic & Empirical & Book & Australia & 2009 \\
\hline & Tapscott & Enthusiast & Empirical & Book & USA & 2009 \\
\hline & $\begin{array}{l}\text { Hosein, Ramanau } \\
\& \text { J ones }\end{array}$ & Critic & Empirical & Journal & UK & 2010 \\
\hline & $\begin{array}{l}\text { Hosein, Ramanau } \\
\& J \text { ones }\end{array}$ & Critic & Empirical & Conference & UK & 2010 \\
\hline & Jones \& & Critic & Theoretical & Journal & UK/ South & 2010 \\
\hline & Czerniewicz & & & & Africa & \\
\hline & Jones & Critic & Theoretical & Conference & UK & 2010 \\
\hline & Jones et al. & Critic & Empirical & Journal & UK & 2010 \\
\hline & $\begin{array}{l}\text { Littlejohn, } \\
\text { Margaryan \& Vojt }\end{array}$ & Critic & Empirical & Journal & UK & 2010 \\
\hline & $\begin{array}{l}\text { Ramanau, Hosein } \\
\text { \&J ones }\end{array}$ & Critic & Empirical & Conference & UK & 2010 \\
\hline & Schulmeister & Critic & Theoretical & Journal & Germany & 2010 \\
\hline & Sharpe & Critic & Theoretical & Report & UK & 2010 \\
\hline & Sánchez et al. & Critic & Empirical & J ournal & Chile & 2011 \\
\hline & $\begin{array}{l}\text { Gros, García \& } \\
\text { Escofet }\end{array}$ & Critic & Empirical & Journal & Spain & 2012 \\
\hline & Romero et al. & Critic & Empirical & Journal & Spain & 2013 \\
\hline & Lai \& Hong & Critic & Empirical & Journal & New Zeland & 2014 \\
\hline $\begin{array}{l}\text { Boomer } \\
\text { babies }\end{array}$ & Howe \& Strauss & Enthusiast & Theoretical & Book & $\overline{\mathrm{USA}}$ & 2000 \\
\hline Boomlets & Howe \& Strauss & Enthusiast & Theoretical & Book & $\overline{\mathrm{USA}}$ & 2000 \\
\hline \multirow{11}{*}{$\begin{array}{l}\text { Digital } \\
\text { Learners }\end{array}$} & Brown* & Enthusiast & Theoretical & $\overline{\text { J ournal }}$ & $\overline{\mathrm{USA}}$ & 2000 \\
\hline & Bullen et al. & Critic & Empirical & Journal & Canada & 2008 \\
\hline & Qayyum et al. & Critic & Empirical & Journal & Canada & 2008 \\
\hline & Bullen et al. & Critic & Empirical & J ournal & Canada & 2009 \\
\hline & Cantoni \& Tardini & Critic & Theoretical & Journal & Switzerland & 2010 \\
\hline & Bullen \& Morgan & Critic & Empirical & Journal & Canada & 2011 \\
\hline & $\begin{array}{l}\text { Bullen, Morgan \& } \\
\text { Qayyum }\end{array}$ & Critic & Empirical & Journal & Canada & 2011 \\
\hline & Romero et al. & Critic & Empirical & J ournal & Spain & 2011 \\
\hline & $\begin{array}{l}\text { Littlejohn, } \\
\text { Beetham \& McGill }\end{array}$ & Critic & Empirical & Journal & UK & 2012 \\
\hline & Morgan \& Bullen & Critic & Empirical & J ournal & Canada & 2013 \\
\hline & Romero et al. & Critic & Empirical & Journal & Spain & 2013 \\
\hline Gen.com & Howe \& Strauss & Enthusiast & Theoretical & Book & USA & 2000 \\
\hline Generation & Howe \& Strauss & Enthusiast & Theoretical & Book & USA & 2000 \\
\hline Next & Tapscott & Enthusiast & Empirical & Book & USA & 2009 \\
\hline Generation & Howe \& Strauss & Enthusiast & Theoretical & Book & USA & 2000 \\
\hline
\end{tabular}


Let's Talk about Digital Learners in the Digital Era

Gallardo-Echenique, Marqués-Molías, Bullen, and Strijbos

\begin{tabular}{|c|c|c|c|c|c|c|}
\hline Tech & & & & & & \\
\hline $\begin{array}{l}\text { Generation } \\
\text { Why }\end{array}$ & Howe \& Strauss & Enthusiast & Theoretical & Book & $\overline{\text { USA }}$ & 2000 \\
\hline $\begin{array}{l}\text { Generation } \\
\text { XX }\end{array}$ & Howe \& Strauss & Enthusiast & Theoretical & Book & $\overline{\text { USA }}$ & 2000 \\
\hline $\begin{array}{l}\text { Generation } \\
2000\end{array}$ & Howe \& Strauss & Enthusiast & Theoretical & Book & USA & 2000 \\
\hline Nexters & $\begin{array}{l}\text { Zemke, Raines \& } \\
\text { Filipczak }\end{array}$ & Concerned & Theoretical & Book & $\overline{\text { USA }}$ & 2000 \\
\hline \multirow{5}{*}{ Cyberkid } & $\begin{array}{l}\text { Holloway \& } \\
\text { Valentine* }\end{array}$ & Concerned & Theoretical & Book & UK & 2001 \\
\hline & Valentine \& & Concerned & Empirical & J ournal & UK & 2002 \\
\hline & Holloway & & & & & \\
\hline & $\begin{array}{l}\text { Holloway \& } \\
\text { Valentine }\end{array}$ & Concerned & Theoretical & Book & UK & 2003 \\
\hline & Holmes & Critic & Empirical & Journal & UK & 2011 \\
\hline \multirow{26}{*}{$\begin{array}{l}\text { Digital natives } \\
\text { and digital } \\
\text { immigrants }\end{array}$} & Prensky* & Enthusiast & Theoretical & J ournal & $\overline{\text { USA }}$ & 2001 \\
\hline & Carlson & Concerned & Empirical & J ournal & USA & 2005 \\
\hline & Gaston & Enthusiast & Empirical & J ournal & USA & 2006 \\
\hline & Prensky & Enthusiast & Theoretical & J ournal & USA & 2006 \\
\hline & Prensky & Enthusiast & Theoretical & Report & USA & 2007 \\
\hline & $\begin{array}{l}\text { Bennett, Maton \& } \\
\text { Kervin }\end{array}$ & Critic & Theoretical & Journal & Australia & 2008 \\
\hline & Kennedy et al. & Critic & Empirical & Conference & Australia & 2008 \\
\hline & Kennedy et al. & Critic & Empirical & Journal & Australia & 2008 \\
\hline & Palfrey \& Gasser & Enthusiast & Empirical & J ournal & USA & 2008 \\
\hline & Maclean \& Elwood & Critic & Empirical & $\begin{array}{l}\text { Book } \\
\text { Chapter }\end{array}$ & Japan & 2009 \\
\hline & Bennett \& Maton & Critic & Theoretical & J ournal & Australia & 2010 \\
\hline & $\begin{array}{l}\text { Brown \& } \\
\text { Czerniewicz }\end{array}$ & Critic & Empirical & J ournal & South Africa & 2010 \\
\hline & $\begin{array}{l}\text { Czerniewicz \& } \\
\text { Brown }\end{array}$ & Critic & Empirical & Conference & South Africa & 2010 \\
\hline & Helsper \& Eynon & Critic & Theoretical & J ournal & UK & 2010 \\
\hline & Kennedy et al. & Critic & Theoretical & Journal & Australia & 2010 \\
\hline & Kolikant & Critic & Empirical & J ournal & Israel & 2010 \\
\hline & Li \& Ranieri & Critic & Empirical & J ournal & China & 2010 \\
\hline & Prensky & Enthusiast & Theoretical & Book & USA & 2010 \\
\hline & $\begin{array}{l}\text { Salajan, } \\
\text { Schönwetter \& } \\
\text { Cleghorn }\end{array}$ & Critic & Empirical & J ournal & Canada & 2010 \\
\hline & Selwyn & Critic & Theoretical & J ournal & UK & 2010 \\
\hline & Thinyane & Critic & Empirical & Journal & South Africa & 2010 \\
\hline & Koutropoulos & Critic & Theoretical & Journal & USA & 2011 \\
\hline & $\begin{array}{l}\text { Margaryan, } \\
\text { Littlejohn \& Vojt }\end{array}$ & Critic & Empirical & J ournal & UK & 2011 \\
\hline & Thomas & Critic & Empirical & Book & Australia & 2011 \\
\hline & Smith & Critic & Theoretical & J ournal & Canada & 2012 \\
\hline & Lai \&Hong & Critic & Empirical & Journal & New Zeland & 2014 \\
\hline $\begin{array}{l}\text { Instant- } \\
\text { Message } \\
\text { generation }\end{array}$ & $\begin{array}{l}\text { Lenhart, Rainie \& } \\
\text { Lewis }\end{array}$ & Enthusiast & Empirical & Report & USA & 2001 \\
\hline Generation & Martin \& Tulgan & Enthusiast & Theoretical & Book & USA & 2002 \\
\hline
\end{tabular}


Let's Talk about Digital Learners in the Digital Era

Gallardo-Echenique, Marqués-Molías, Bullen, and Strijbos

\begin{tabular}{|c|c|c|c|c|c|c|}
\hline $\begin{array}{l}\operatorname{mix}(G e n \\
\text { Mixers) }\end{array}$ & Martin \& Tulgan & Enthusiast & Theoretical & Book & USA & 2006 \\
\hline $\begin{array}{l}\text { Internet-savvy } \\
\text { students }\end{array}$ & Levin \&Arafeh & Enthusiast & Empirical & Report & USA & 2002 \\
\hline $\begin{array}{l}\text { MTV } \\
\text { generation }\end{array}$ & Guzdial \& Soloway & Enthusiast & Empirical & Journal & $\overline{\mathrm{USA}}$ & 2002 \\
\hline \multirow{3}{*}{$\begin{array}{l}\text { Homo } \\
\text { zappiens }\end{array}$} & Veen* & Enthusiast & Theoretical & Journal & Netherlands & 2003 \\
\hline & Veen \& Vrakking & Enthusiast & Theoretical & Book & Netherlands & 2006 \\
\hline & Veen & Enthusiast & Theoretical & Conference & Netherlands & 2007 \\
\hline $\begin{array}{l}\text { Gamer } \\
\text { generation } \\
\end{array}$ & Carstens \& Beck & Enthusiast & Empirical & J ournal & USA & 2005 \\
\hline \multirow{2}{*}{$\begin{array}{l}\text { Generation M } \\
\text { (media) }\end{array}$} & $\begin{array}{l}\text { Roberts, Foehr \& } \\
\text { Rideout* }\end{array}$ & Enthusiast & Empirical & Report & $\overline{\mathrm{USA}}$ & 2005 \\
\hline & $\begin{array}{l}\text { Rideout, Foehr \& } \\
\text { Roberts }\end{array}$ & Enthusiast & Empirical & Report & USA & 2010 \\
\hline \multirow{3}{*}{$\begin{array}{l}\text { Generation } \\
\mathrm{Me}\end{array}$} & Twenge* & Concerned & Theoretical & Book & USA & 2006 \\
\hline & Twenge & Concerned & Theoretical & Journal & USA & 2009 \\
\hline & Tapscott & Enthusiast & Empirical & Book & USA & 2009 \\
\hline New & Pedró* & Critic & Empirical & Report & France & 2006 \\
\hline $\begin{array}{l}\text { millennial } \\
\text { learners }\end{array}$ & Pedro & Critic & Empirical & Conference & Belgium & 2009 \\
\hline \multirow{2}{*}{ ScreenAgers } & Rushkoff* & Enthusiast & Theoretical & Book & USA & 2006 \\
\hline & Tapscott & Enthusiast & Empirical & Book & USA & 2009 \\
\hline $\begin{array}{l}\text { Clicking } \\
\text { replaces } \\
\text { thinking }\end{array}$ & Brabazon* & Concerned & Theoretical & Book & Australia & 2007 \\
\hline Generation C & $\begin{array}{l}\text { Duncan-Howell \& } \\
\text { Lee* }\end{array}$ & Enthusiast & Theoretical & Conference & Australia & 2007 \\
\hline \multirow[t]{2}{*}{$\begin{array}{l}\text { Google } \\
\text { generation }\end{array}$} & $\begin{array}{l}\text { Nicholas, } \\
\text { Rowlands \& } \\
\text { Huntington* }\end{array}$ & Critics & Empirical & Report & UK & 2007 \\
\hline & Rowlands et al. & Critics & Empirical & Conference & UK & 2008 \\
\hline $\begin{array}{l}\text { MySpace } \\
\text { generation }\end{array}$ & Rosen & Concerned & Empirical & Book & USA & 2007 \\
\hline Born digital & Palfrey \& Gasser* & Enthusiast & Empirical & Book & USA & 2008 \\
\hline \multirow{2}{*}{ Digital settlers } & Weinberger* & Critics & Theoretical & J ournal & USA & 2008 \\
\hline & Palfrey \& Gasser & Enthusiast & Empirical & Book & USA & 2008 \\
\hline $\begin{array}{l}\text { Dumbest } \\
\text { generation }\end{array}$ & Bauerlein & Concerned & Empirical & Book & USA & 2008 \\
\hline $\begin{array}{l}\text { Facebook } \\
\text { generation }\end{array}$ & Kitsis* & Enthusiast & Empirical & J ournal & $\overline{\mathrm{USA}}$ & 2008 \\
\hline $\begin{array}{l}\text { Digital } \\
\text { melting pot }\end{array}$ & Stoerger* & Critic & Theoretical & J ournal & USA & 2009 \\
\hline \multirow{3}{*}{$\begin{array}{l}\text { Digital } \\
\text { wisdom }\end{array}$} & Prensky* & Enthusiast & Theoretical & $\begin{array}{c}\text { Book } \\
\text { chapter }\end{array}$ & USA & 2009 \\
\hline & Skiba & Enthusiast & Theoretical & J ournal & USA & 2010 \\
\hline & Prensky & Enthusiast & & & USA & 2011 \\
\hline \multirow{3}{*}{$\begin{array}{l}\text { Visitors and } \\
\text { Residents }\end{array}$} & White* \& Le Cornu & Critic & Empirical & J ournal & USA & 2011 \\
\hline & $\begin{array}{l}\text { Connaway, White } \\
\text { \&Lanclos }\end{array}$ & Critic & Empirical & J ournal & USA & 2011 \\
\hline & $\begin{array}{l}\text { Connaway, Lanclos } \\
\& \text { Hood }\end{array}$ & Critic & Empirical & Conference & USA/UK & 2013 \\
\hline
\end{tabular}


Let's Talk about Digital Learners in the Digital Era

Gallardo-Echenique, Marqués-Molías, Bullen, and Strijbos

\begin{tabular}{|c|c|c|c|c|c|c|}
\hline & $\begin{array}{l}\text { Connaway, White } \\
\text { \&Lanclos }\end{array}$ & Critic & Empirical & J ournal & USA/UK & 2013 \\
\hline Digitizen & $\begin{array}{l}\text { Brown \& } \\
\text { Czerniewicz** }\end{array}$ & Critic & Empirical & J ournal & South Africa & 2010 \\
\hline e-generation & Liu & Critic & Empirical & Journal & China/ Norway & 2010 \\
\hline i-Generation & $\begin{array}{l}\text { Rosen, Carrier \& } \\
\text { Cheever* }\end{array}$ & Concerned & Empirical & Book & USA & 2010 \\
\hline $\begin{array}{l}\text { Learners of } \\
\text { Digital Era }\end{array}$ & $\begin{array}{l}\text { Rapetti \& Cantoni* } \\
\text { Rapetti } \\
\text { Rapetti } \\
\text { Rapetti \& Cantoni }\end{array}$ & $\begin{array}{l}\text { Critic } \\
\text { Critic } \\
\text { Critic } \\
\text { Critic }\end{array}$ & $\begin{array}{l}\text { Empirical } \\
\text { Theoretical } \\
\text { Empirical } \\
\text { Empirical }\end{array}$ & $\begin{array}{l}\text { Conference } \\
\text { Conference } \\
\text { Thesis } \\
\text { Conference }\end{array}$ & $\begin{array}{l}\text { Switzerland } \\
\text { Switzerland } \\
\text { Switzerland } \\
\text { Switzerland }\end{array}$ & $\begin{array}{l}2010 \\
2011 \\
2012 \\
2013\end{array}$ \\
\hline $\begin{array}{l}\text { Digital nerds } \\
\text { and digital } \\
\text { normal }\end{array}$ & $\begin{array}{l}\text { Thirunarayanan et } \\
\text { al.* }\end{array}$ & Critic & Empirical & J ournal & USA & 2011 \\
\hline $\begin{array}{l}\text { App } \\
\text { Generation }\end{array}$ & Gardner \& Davis & Concerned & Empirical & Book & USA & 2013 \\
\hline
\end{tabular}

Note: Personal compilation, *who coined the term

The term "Digital Native" was coined by Prensky (2001a, 2001b), but "Prensky is not specific about the dates that define this new generation" (J ones \& Czerniewicz, 2010, p. 317). Prensky uses the terms "Digital Native" and "Digital Immigrant" to distinguish between those who were not born into the digital world (Prensky, 2001a) and those who have grown up familiar with multiple technologies, but Prensky is using generational categorisation (students born roughly between 1980 and 1994) to over-determine student characteristics and relations to technology. Prensky's main point is that this new generation is essentially different from previous generations because of their constant and frequent use of digital technologies. Rather than calling "Digital Natives" a generation, Palfrey and Gasser (2008) prefer to think of them as a population, i.e. a social group with common characteristics. Like Prensky, Palfrey and Gasser (2008) use the term "Digital Native" to describe advanced users of technology who were born after 1980. Digital immigrantsas opposed to digital natives - are not people who were born digital and/ or live a digital life in any substantial way, but rather people who are finding their way in a digital world.

According to Tapscott $(1998,2009)$ the Net Generation includes those born between 1977 and 1997 (Tapscott, 2009) and the defining characteristic of the generation is that "they were the first to grow up in a digital world" (Tapscott, 2009, p. 2). Following J ones and Czerniewicz (2010), the general claim by the Net Generation discourse is around young people developing a natural aptitude and high skill levels in relation to new technologies. Moreover, according to Rapetti and Cantoni (2010b), the Net Generation label focuses the attention on the main supposed difference of this "new" generation, that is, the frequency and the ability in using Internet for formal and informal learning purposes.

Millennials, also known as Generation Y, is the largest generation since the baby boom generation 
(Howe \& Strauss, 2000; Coomes \& DeBard, 2004; Norum, 2008). Howe and Strauss (2000) refer to "Millennials" (students born between 1980 and 2000) as the first generation to have technology and the Internet from a very early age, and much of their activity involving peer-topeer communication and knowledge management is mediated by these technologies (Djamasbi, Siegel, \& Tullis, 2010). However, Oblinger and Oblinger (2005) date the Millennials more narrowly as those born between the years 1982-1991. Howe and Strauss (2000) mention seven key characteristics of Millennials: special, sheltered, confident, conventional, team-oriented, achieving and pressured. Millennials are described as having a focus on social interaction and "connectedness", via instant messenger, cellular conversations or text messaging, with friends, family and colleagues, and preferring group-based approaches to study and social activities (McMahon \& Pospisil, 2005; Pedró, 2006).

Each "enthusiast" author (see Table 2) also proposed his/ her own list of characteristics that they believe best define this new student generation. Table 3 summarizes the major claims (characterizations/ definitions) made about the "Digital Native" discourse. 
Table 3

Key Claims about the “Digital Native” Discourse

\begin{abstract}
Key claim
Want to get along by being team-oriented and have a desire to cooperate and be perceived as being cooperative.

Marked ability to multitask with a variety of digital technologies.
\end{abstract}

\section{Author}

Downing, 2006; Howe \& Strauss, 1991; 2000;

Lancaster \& Stillman, 2002; Martin \& Tulgan, 2002, 2006; Oblinger, 2003; Oblinger \& Hawkins, 2005; Oblinger \& Oblinger, 2005; Prensky, 2010; Tapscott, 1998; 2009 Frand, 2000; Lancaster \& Stillman, 2002; Gaston, 2006; Oblinger, 2003; Oblinger \& Hawkins, 2005; Prensky, 2001b; Rosen, 2010; Simoneaux \& Stroud, 2010; Tapscott, 1998; 2009; Zemke, Raines \& Filipczak, 2000

Need to acknowledge and to drive a digital revolution by transforming society. Need to think in terms of transforming the educational experience.

Seen as innately or inherently tech-savvy as opposed to older generations.

Frand, 2000; Howe \& Strauss, 1991; 2000; Oblinger, 2003; Oblinger \& Hawkins, 2005; Oblinger \& Oblinger, 2005; Prensky, 2001a; Tapscott, 1998; 2009

Oblinger, 2003; Oblinger \& Hawkins, 2005;

Oblinger \& Oblinger, 2005; Prensky, 2010;

Tapscott, 1998; 2009

Need for achievement and detailed instructions/guidelines for assignments. DeBard, 2004; Howe \& Strauss, 2000; Martin \& Tulgan, 2002, 2006

Possess new learning styles or different ways of knowing and being. Brown, 2000; Frand, 2000; Howe \& Strauss, 1991; 2000; Oblinger, 2003; Oblinger \& Hawkins, 2005; Oblinger \& Oblinger, 2005; Prensky, 2001a Need for constant connectivity; being in touch with friends and family at any time and from any place. Purported as native speakers of computers, video games, and the Internet. Preference for online/ offline games and interactive simulations to serious work. Frand 2000; Oblinger \& Oblinger, 2005; Prensky, 2001b, 2006; Rosen, 2010

Marked preference for image over text based content.

Confident in the knowledge that they have in their use of technologies. Optimistic about their future.
Brown, 2002; Prensky, 2001a; Prensky, 2010

Downing, 2006; Frand, 2000; Oblinger, 2003; Prensky, 2001a; Tapscott, 1998; 2009 Prensky, 2001a , 2001b; Tapscott, 2009

Downing, 2006; Howe \& Strauss, 2000; Martin \& Tulgan, 2002, 2006; Taylor \& Keeter, 2010 


\section{Many Terms, Three Views}

Whatever the terminology, it is an accurate claim that today's students - in the developed world at least - have been exposed to a wide range of digital technologies which did not previously exist (Brown \& Czerniewicz, 2010). The exposure to technology is a critical element in determining some of the characteristics attributed to these students. Common to the multitude and proliferation of similar and/ or related concepts to describe these students, is that all of these concepts suggest somehow the idea of a digitalized/ technologized generation (Rapetti \& Cantoni, 2010b). Moreover, the age boundary between the generations varies - given the source - from 1977 to 1984 and others from 1990 to 2000.

Furthermore, a variety of approaches have been used to research this issue: for example, (a) empirical-quantitative research, mainly via questionnaires; (b) collection of evidence from a given context followed by generalization (which could be considered an extension of the case-study method); (c) socio-historical analyses; and, (d) theoretical reflection, including pedagogical implications (Rapetti, 2011, 2012). To make sense of the many definitions and the growing body of research, Rapetti (2012) suggests three views to understand how authors perceive and define learners' use of ICT: enthusiasts, concerned ones, and critics (detailed descriptions are provided in Table 4).

Table 4

Three Different Views of the Debate

Enthusiasts

These authors are firmly convinced that digital technologies contribute a specific set of skills to learners.

Concerned ones

These authors accept the idea of a digitalized generation of learners, but focus on the potential dangerous effects, such as violence, dumbness, harassment, addiction, etc. (e.g., Bauerlein, 2008).

These authors question the idea of characterizing the set of skills of the younger generation simply as a function of ICTs' use, criticize overgeneralizations, and request more in-depth studies and localized analyses (e.g., Bullen et al., 2009).

Note. Adapted from “LoDE: Learners of Digital Era”, by Rapetti, 2012, p. 144.

Given the large variety in (a) terms and concepts, (b) generational boundaries, and (c) views on learners' use of ICTs in education, the next section proposes "digital learner" as a unifying concept. 


\section{Time for a Unifying Concept: A Critical View}

There is a growing body of academic research that questions the validity of the generational assumption included in the digital native concept: "Contrary to the argument put forward by proponents of the digital native concept, generation alone does not adequately define if someone is a digital native or not" (Helsper \& Eynon, 2010, p. 515). Research conducted in Switzerland concludes that it is unrealistic to attribute behaviors and characteristics by simplistically basing them on generational "virtues" (Rapetti \& Cantoni, 2010a). Through the analysis of a nationally representative survey in the UK, Helsper and Eynon (2010) conclude that their analysis does not support the view that there are unbridgeable differences between those who can be classified as digital natives or digital immigrants based on when they were born. A research project by Rapetti and Marshall (2010) at the University of the West Indies concluded that the quantitative and qualitative data do not reveal the expected enthusiastic appreciation, that is, "the age factor has a discrete impact on certain aspects (e.g., the familiarity with the new digital devices), but cannot be considered as the variable explaining how current learners face ICTs" (p. 78). According to Brown and Czerniewicsz (2010) age is not a determining factor in the digital lives of South African higher education students. They also demonstrate that (a) the notion of a generation of "Digital Natives" is inaccurate, that is, being a "Digital Native" was not about age but about experience, access and opportunity (Brown \& Czerniewicz, 2010; Czerniewicz \& Brown, 2010) and (b) the term could only be applied to a small and elite group of students (Czerniewicz \& Brown, 2010).

To Kennedy et al. (2008), arguments about digital natives also warrant closer examination: "These arguments are predicated on a general assumption that students coming into universities have had a comparatively universal and uniform digital upbringing" (p. 109). Their study highlights the lack of homogeneity in the incoming first year Australian university students' population with regard to technology. They found that undergraduates were highly proficient at using digital technologies, but when one moved beyond entrenched technologies and tools (e.g., computers, mobile phones, email), "the proficiency and confidence in a range of other technologies that are commonly used in schools show considerable variation" (Kennedy et al., 2008, p. 117).

Despite perpetuating the digital native rhetoric in their book, "Born digital: Understanding the first generation of digital natives", Palfrey and colleagues consider "digital native" an "awkward term" (Palfrey, Gasser, Simun, \& Barnes, 2009), however, they embrace it "because of its cultural resonance with the parents, teachers, and policymakers" (Palfrey et al., 2009, p. 83). Brown and Czerniewicz (2010) find the concept of the "Digital Native" especially problematic, both empirically and conceptually, and even likely to be offensive as a term. They argue that this term establishes a binary opposition between those who are "natives" and those who are not, the so-

called "digital immigrants", and "This polarization makes the concept less flexible and more 
determinist in that it implies that if a person falls into one category, they cannot exhibit characteristics of the other category" (Brown \& Czerniewicz, 2010, p. 357).

Salajan, Schönwetter and Cleghorn (2010) analysed the digital native-digital immigrant dichotomy via a small-scale study at the University of Toronto and conclude that this duality is somewhat problematic, arbitrary and misleading. Their results suggest that there are age-related differences in how the so-called digital natives and digital immigrants interface with digital technologies, but these differences are minimal, with no universal applicability (Salajan et al., 2010). Moreover, even Prensky who coined the term "digital natives and digital immigrants", has suggested this distinction may no longer be relevant and now talks instead about digital wisdom (Prensky, 2009) and highlights the necessity of cultivating digital wisdom for the profit of enhancing natural human intellectual capacities through digital technology (Prensky, 2011). In his defence, Prensky (2011) also mentioned that many people have been interpreting "very literally rather than metaphorically - what a 'Digital Native' was' (p. 29).

Nicholas, Rowlands, and Huntington (2007) investigated how British school children (age between 11 and 15) used Internet search engines and found their search skills to be much less advanced than educators tend to think. Moreover, other researchers found that the characterization of young people as "Digital Natives" hides many contradictions within and between their individual experiences (Luckin, Clark, Logan, Graber, Oliver, \& Mee, 2009; Littlejohn \&Margaryan, 2010; Littlejohn, Beetham, \& McGill, 2012).

In the literature students are sometimes assumed to feel empowered with respect to learning because of their familiarity with and access to ICT (Kolikant, 2010). However, this topic has generated controversy. On the one hand, some argue that "Digital Natives" are sophisticated users of new technologies who critically analyse the information they access online (Frand, 2000; Levin \& Arafeh, 2002; Gaston, 2006). According to Virkus (2008) these new students are: better at taking in information, making decisions quickly, multi-tasking, parallel processing and thinking graphically rather than textually; assume connectivity and see the world through the lens of games and play; have a diversity of experiences and needs, and they are expecting instant responses and feedback; and, are goal and achievement oriented. On the other hand, most of the academic research on this topic (Kennedy et al., 2008; Bennett et al., 2008; Brown \& Czerniewicz, 2010; Li \& Ranieri, 2010) shows that "Digital Natives", in fact, appear to have a superficial understanding of the new technologies, use the new technologies for very limited and specific purposes, and have superficial information-seeking and analysis skills. In recent years, empirical research into Net Generation students' use of, and preferences for, technologies in higher education revealed that "while most students regularly use established technologies such as email and Web searching, only a small subset of students use more advanced or newer tools and technologies" (Kennedy et al., 2010, p. 333). 
A more extensive empirical study (Kennedy et al. 2007; Kennedy et al. 2008), conducted in 2006 with more than 2,000 incoming first year Australian university students, compared digital natives and immigrants with regard to technology use. The study examined what tools were used and how frequently. This research showed there is no fundamental difference between digital natives and immigrants and suggested that the digital native characteristics can be found only among a minority of students. Another study among first-year students across seven faculties of an Australian university, also demonstrated that there is enough diversity in ability, access and use of technology by the students to suggest that a technological homogenous group of students cannot be assumed (Corrin, Lockyer, \& Bennett, 2010). A meta-analysis of learners' experiences of elearning by Sharpe (2010) revealed that we should not make assumptions about learners' digital competencies and literacies when they enter higher education. A similar observation was made by Margaryan, Littlejohn and Vojt (2011, p. 439) from a recent study conducted in two UK universities, who suggest that "decisions surrounding the use of technologies for learning should not only be based around students' preferences and current practices, but on a deep understanding of what the educational value of these technologies is and how they improve the process and the outcomes of learning". Salomon (2000) eloquently summarized this in his call to "let technology show us what can be done, and let educational considerations determine what will be done" (If it ain't technology, what is it then?, para. 5).

Research exploring new generation learners and their relationship to technology has also been undertaken outside of the advanced industrial countries (J ones et al., 2010). A survey conducted in 2007 of 3,533 students regarding ICT use in six higher education institutions in five South African provinces, revealed that new technologies are infrequently used despite the hype associated with Web 2.0 technologies (Brown \& Czerniewicz, 2008). Moreover, Brown and Czerniewicz (2008) concluded that these findings were similar to findings in the UK and US. Another study conducted in 2009 of 292 first year students at two South African universities about their access to and use of technology revealed that the students (a) did not appear not to use such technologies, and (b) were not even interested in using them in their studies with the exception of tasks involving the mobile phone (Thinyane, 2010) - which clearly points to differences between students' experiences and use of ICTs in developed and developing countries (Thinyane, 2010).

Despite the widespread acceptance of the concept of the "Digital Native", the key claims of this discourse are not based on empirical research. In fact, in the paper "Digital natives, digital immigrants" in which Prensky (2001a, 2001b) proposes these terms, he does not cite any systematic and methodologically sound empirical research to support his ideas. Instead, the key claims are based on popular and quasi-academic literature and tend to be informed by anecdotal research and proprietary research funded by and conducted for private business (Bullen, Morgan, \&Qayyum, 2011; Bullen \&Morgan, 2011). The studies by Bullen and colleagues suggest that there are no meaningful differences between net generation and non-net generation students at a postsecondary institution in Western Canada in terms of their use of technology, or in their 
behavioural characteristics and learning preferences. The findings show that today's learners, regardless of age, are on a continuum of technological access, skill, use and comfort. They have differing views about the integration of social and academic uses and are not generally challenging the dominant academic paradigm (Bullen \& Morgan, 2011). In sum, there is little evidence "to support a claim that digital literacy, connectedness, a need for immediacy, and a preference for experiential learner were characteristics of a particular generation of learners" (Bullen et al., 2009, p. 10).

\section{Digital Learners, Not Digital Natives}

Bennett and Maton (2010) also refute the notion of the "Digital Native" because of its widespread popularity on the basis of claims rather than evidence and highlight the complexities of young people's technology experiences. To Thirunarayanan et al. (2011), the idea that there are digital natives and digital immigrants is yet to be proven by research. Findings of their study carried out with two freshmen year classes in a large, public, urban university, reveal that some of the assumptions made by Prensky (2001a; 2001b) are definitely not valid. For example, Prensky (2001a, p. 1) states: "Our students today are all 'native speakers' of the digital language of computers, video games and the Internet", but the data from the Thirunarayanan et al. (2011) study does not support such enthusiasm or optimism and also suggests that not all students use all the digital tools available for study and/ or in society.

Bullen and colleagues, who supported the term "digital learner" early on, reviewed the research on "Digital Natives" conducted in six different countries and at a range of different institutions, and concluded that there is no empirical basis for the notion of digital native. They argue that it is a social and not a generational issue and that the implications for education are far from clear (Bullen, Morgan, Belfer, \& Qayyum, 2008; Bullen \& Morgan, 2011; Bullen, Morgan, \& Qayyum, 2011). The assumption that students - born roughly between 1980 and 1994 - have natural digital skills, is not commonly-accepted. Generalizations based on "generational differences" are not useful for discussions concerning teaching and learning. How learners use digital technologies is a complex issue that goes much deeper than age. We also need to take into account young people with less skills in the use of technologies, the conditions of access and use of information, the neglect of the impact of contextual, economic, political, social, historical and cultural factors that increase the so-called "digital gap" between those who have access to the information and those who do not. Factors such as gender, education, experience, social inclusion and exclusion, culture, institutional context, subject discipline, learning design, and the socio-economic background of students are far more important and researchers have only recently begun to examine them (Kennedy et al., 2010; Margaryan et al., 2011). Hence, "It is time to put the digital natives discourse to rest and focus on digital learners" (Bullen \& Morgan, 2011, p. 66).

This work is licensed under a Creative Commons Attribution 4.0 International License. 
According to Rapetti (2012, p. 39), the expression digital learners "is meant to refer generically (and synthetically) to all those labels (Digital Natives, Generation Y, Net Generation, etc.) assuming that the current generation of learners has been so deeply affected by ICTs to the extent we must consider them as 'digital'". In addition, Rapetti and Cantoni (2010b) coined a new term "Learners of Digital Era" (LoDE) and suggest that age is not the sole factor to be considered. The LoDE perspective is summarized by the following four facets (Rapetti \& Cantoni, 2010b, p. 5):

- The focus is on persons, so the first word refers to them.

- The perspective is anthropological-pedagogical, so the chosen word is "learning".

- Not only young people learn through ICTs in the Knowledge Society.

- The lesson learnt from the "Digital Natives" label: the pervasion of digital technologies in everyday life has a great impact on learning experiences, but we should refuse to apply the "digital" adjective to people and imply generational divides.

We do not think that there is very much difference between LoDE and digital learner. Like us, Rapetti and Cantoni (2010b) reject terms that are based on age or generation and we think their term is just a different way of making the same point. Yet, we find the term "digital learner" simpler because: (a) it offers a more global vision of the 21st century student in the digital age (i.e., not assuming that learners can use digital technologies by default and automatically want to study with digital tools; to focus on how to apply/ implement digital tools that assist learners with their learning); (b) it is more readily suited/ usable in practice; and, (c) it is substantially enriched by the misunderstandings, myths and fallacies highlighted by all the critical views. Table 5 summarizes the characteristics of the "digital learner" proposal as a unifying concept.

Table 5

Digital Learner proposal

Digital Learner

a) focuses on "learners" rather than "persons", who should realize the possibilities and potentials of digital technologies in their environments and recognize the value of technology and the opportunity it presents the learner in his/ her daily life,

b) argues that learners are not merely users or consumers of technology,

c) highlights the complexities of learner's technology experiences,

d) rejects the generational boundary and any chronological generations that exclude other types of actors who share similar practices (accept all learners),

e) does not assume any pre-defined learner characteristics, and

f) adopts a socio-cultural, anthropological, communicational and pedagogical approach from the learners' perspective. 


\section{Implications for Practice and Policy}

One major implication that may be inferred from this study is that the multitude of terms used, and ensuing conceptual confusion, resulted in an unfocused and unproductive debate. The use of a unifying concept (without people continuously suggesting new terms that are hyped) will streamline and lead to a hopefully more focused and productive discussion. It is more fruitful to discuss what the needs are of digital learners, how staff can respond to those needs and what they need to know to be able to do so, and how technologies can be designed that are responsive to the needs of the digital learner. We are convinced that it is important to bring together academics, policy makers and practitioners from many different backgrounds in order to consider the contexts and consequences of use of digital technologies for digital learners. The so called "Digital Natives" perspective seems to be inappropriate or insufficient to describe the population of current learners, because some features of the widespread expression "Digital Natives" and many associated assumptions have been demystified (Rapetti \& Marshall, 2010; Rapetti \& Cantoni, 2010a). There is no absolute definition of digital native: it will vary among individuals, societies, regions and nations, and also over time. Generalizations based on "generational differences" are not useful for discussions concerning teaching and learning. To understand the implications for those who learn, we must develop a comprehensive understanding of how learners use digital technologies, focus on the implications of being a learner in a digital era and try to develop a comprehensive understanding of the issues that take into account factors such as age, gender, education, experience, social inclusion and exclusion, culture, institutional context, subject discipline, learning design, and socio-economic background.

\section{Conclusions and Recommendations}

Our integrative review of the literature demonstrated an extensive theoretical and terminological diversity related to the notion of the "Digital Native". Over the years a variety of terms have been proposed as well as a multiplicity of definitions: some similar, others quite different and many of them redundant. For that reason, we propose to unify these concepts under the term "digital learners". In our view the term digital learner is the most useful term, because it offers a more global vision of the 21 st century student.

Moreover, while research around learners in the digital era is just beginning and may need more critical examination - and the body of theoretical literature in education that explores concepts and characteristics around learners in the digital era is still growing - it is critical that we move beyond the superficial dichotomy of "natives" and "immigrants", focus on the implications of being a learner in a digital era, and "try to develop a comprehensive understanding of the issues

This work is licensed under a Creative Commons Attribution 4.0 International License. 
that take into account the diversity of cultural and institutional contexts"' (Bullen \& Morgan, 2011, p. 63).

Despite the general belief that "Digital Natives" show greater willingness and ability to use technology, the analysis of the literature demonstrates a clear mismatch between the confidence with which claims are made and the evidence for such claims (Bennett, Maton, \& Kervin, 2008). In that regard, two findings can be drawn from this review. First, there is no commonly-accepted definition of digital native: it varies among individuals, societies, regions and nations, and also over time. Second, there are a number of variables other than age that may help us understand the nature of students' use of digital technologies. Moreover, research does not support the view that digital natives are - by default - digitally competent and that these skills transfer to the academic environment. In fact, there is no evidence that they want to use these technologies for academic purposes. Despite their digital confidence and digital skills, their digital competence the ability to assess and learn from resources - may be much lower than those of their teachers. Thus, "while we can now say with certainty that generation is not relevant" (Bullen \& Morgan, 2011, p. 63), it is necessary to consider other variables besides age that can help us understand the nature of the use of digital technologies by students. 


\section{References}

*References marked with an asterisk indicate the articles used in the review.

Akkerman, S., Admiraal, W., Brekelmans, M., \& Oost, H. (2008). Auditing quality of research in social sciences. Quality \&Quality, 42, 257-274. doi:10.1007/ s11135-006-9044-4

*Bajt, S. K. (2011). Web 2.0 technologies: Applications for community colleges. New Directions for Community Colleges, 2011(154), 53-62. doi:10.1002/ cc.446

*Bauerlein, M. (2008). The dumbest generation: How the digital age stupefies young Americans and jeopardizes our future (or, don't trust anyone under 30). New York: Tarcher/ Penguin.

*Bennett, S., \& Maton, K. (2010). Beyond the 'digital natives' debate: Towards a more nuanced understanding of students' technology experiences. J ournal of Computer Assisted Learning, 26(5), 321-331. doi:10.1111/j.1365-2729.2010.00360.x

*Bennett, S., Maton, K., \& Kervin, L. (2008). The 'digital natives' debate: A critical review of the evidence. British J ournal of Educational Technology, 39(5), 775- 786. doi:10.1111/j.14678535.2007.00793.x

*Downing, K. (2006). Next generation: What leaders need to know about the Millennials. Leadership in Action, 26(3), 3-6. doi:10.1002/lia.1161

*Brabazon, T. (2007). The university of Google: Education in the (post) information age. Aldershot, Hampshire, England: Ashgate.

Braun, V., \& Clarke, V. (2006). Using thematic analysis in psychology. Qualitative Research in Psychology, 3(2), 77-101. doi:10.1191/ 1478088706qp063oa

*Brown, C., \& Czerniewicz, L. (2008). Trends in student use of ICTs in higher education in South Africa. In P. A. van Brakel (Ed.), Proceedings of the 10th annual conference of world wide web applications. Cape Town, South Africa: Cape Peninsula University of Technology.

*Brown, C., \& Czerniewicz, L. (2010). Debunking the 'digital natives': Beyond digital apartheid, towards digital democracy. J ournal of Computer Assisted Learning, 26(5), 357-369. doi:10.1111/j.1365-2729.2010.00369.x 
*Brown, J . S. (2000). Growing up digital: How the web changes work, education, and the ways people learn. Change: The Magazine of Higher Learning, 32(2), 11-20.

doi:10.1080/00091380009601719

*Bullen, M., Belfer, K., Morgan, T., \& Qayyum, A. (2009). The net generation in higher education: Rhetoric and reality. International J ournal of Excellence in E-Learning, 2(1), 1-13.

*Bullen, M., \& Morgan, T. (2011). Digital learners not digital natives. La Cuestión Universitaria, 7, 60-68.

*Bullen, M., Morgan, T., Belfer, K., \&Qayyum, A. (2008). The digital learner at BCIT and implications for an e-strategy. Paper presented at 2008 Research workshop of the European distance education network (EDEN) "Researching and promoting access to education and training: The role of distance education and e-learning in technologyenhanced environments", Paris, France.

*Bullen, M., Morgan, T., \& Qayyum, A. (2011). Digital learners in higher education: Generation is not the issue. Canadian J ournal of Learning and Technology, 37(1), 1-24.

*Cameron, D. (2005). The Net Generation goes to university? In S. M. Stockwell \& B. Isakhan (Eds.), Proceedings of the 2005J ournalism Education Conference. Gold Coast, Queensland, AU: Griffith University, School of Arts.

*Cantoni, L., \& Tardini, S. (2010). Generation Y, digital learners, and other dangerous things [Special issue]. QWERTY - Interdisciplinary J ournal of Technology, Culture and Education, 5(2), 11- 25.

*Carlson, S. (2005). The net generation goes to college. Chronicle of Higher Education, 52(7), A34.

*Carstens, A., \& Beck, J . (2005). Get ready for the gamer generation. TechTrends: Linking Research \& Practice to Improve Learning, 49(3), 22-25. doi:10.1007/ BF02763643

*Czerniewicz, L., \& Brown, C. (2010). Born into the Digital Age in the south of Africa: The reconfiguration of the "digital citizen." In L. Dirckinck-Holmfeld, V. Hodgson, C. J ones, M. de Laat, D. McConnell, \&T. Ryberg (Eds.), Proceedings of the 7th International Conference on Networked Learning 2010 (pp. 859- 865). Aalborg, Denmark: Aalborg University.

Cohen, L., Manion, L., \& Morrison, K. (2007). Research methods in education (6th ed.). London/New York: Routledge. 
*Connaway, L. S., Lanclos, D., \&Hood, E. M. (2013). “I find Google a lot easier than going to the library website." Imagine ways to innovate and inspire students to use the academic library. Proceedings of the Association of College \& Research Libraries (ACRL) 2013 Conference (pp. 289- 300). Indianapolis, IN: American Library Association.

*Connaway, L. S., White, D., \& Lanclos, D. (2011). Visitors and residents: What motivates engagement with the digital information environment? Proceedings of the American Society for Information Science and Technology, 48(1), 1-7. doi:10.1002/meet.2011.14504801129

*Connaway, L. S., White, D., \&Lanclos, D. (2013). Visitors and residents: What motivates engagement with the digital information environment? Information Research, 18(1).

*Coomes, M. D., \&DeBard, R. (Eds.). (2004). A generational approach to understanding students [Special section]. New Directions for Student Services, 2004(106), 5-16. doi:10.1002/ss.121

*Corrin, L., Lockyer, L., \&Bennett, S. (2010). Technological diversity: An investigation of students' technology use in everyday life and academic study. Learning, Media and Technology, 35(4), 387-401. doi:10.1080/ 17439884.2010.531024

*DeBard, R. (2004). Millennials coming to college [Special issue]. New Directions for Student Services, 2004(106), 33-45. doi:10.1002/ss.123

*DiLullo, C., McGee, P., \& Kriebel, R. M. (2011). Demystifying the Millennial student: A reassessment in measures of character and engagement in professional education. Anatomical Sciences Education, 4(4), 214- 26. doi:10.1002/ ase.240

*Djamasbi, S., Siegel, M., \& Tullis, T. (2010). Generation Y, web design, and eye tracking. International J ournal of Human-Computer Studies, 68(5), 307-323. doi:10.1016/j.ijhcs.2009.12.006

*Duncan-Howell, J ., \& Lee, K.-T. (2007). M-learning: Finding a place for mobile technologies within tertiary educational settings. In R. Atkinson, C. McBeath, A. Soong Swee Kit, \& C. Cheers (Eds.), ICT: Providing choices for learners and learning. Proceedings Ascilite 2007 (pp. 223- 232). Singapore: Centre for Educational Development, Nanyang Technological University.

*Frand, J . L. (2000). The information-age mindset: changes in students and implications for higher education. EDUCAUSE Review, 35(5), 14- 24.

*Gardner, H., \& Davis, K. (2013). The app generation: How today's youth navigateidentity, intimacy, and imagination in a digital World. London: Yale University Press. 
*Gaston, J . (2006). Reaching and teaching the digital natives. Library Hi Tech News, 23(3), $12-$ 13. doi:10.1108/07419050610668124

*Gibbons, S. (2007). Redefining the roles of information professionals in higher education to engage the net generation. Paper presented at EDUCAUSE, Australasia. Retrieved from http:// www.caudit.edu.au/educauseaustralasia07/authors_papers/Gibbons2.pdf

*Green, B., Reid, J . A., \& Bigum, C. (1998). Teaching the nintendo generation? Children, computer culture and popular technologies. In S. Howard (Ed.), Wired up: Young people and the electronic media (pp. 19-41). London: UCL Press.

*Gros, B., Garcia, I., \& Escofet, A. (2012). Beyond the net generation debate: A comparison between digital learners in face-to-face and virtual universities. The International Review of Research in Open and Distance Learning, 13(4), 190-210. Retrieved from http:// www.irrodl.org/index.php/irrodl/article/view/ 1305/ 2311

*Guitert, M., Romeu, T., Guerrero, A., \& Padrós, A. (2008). ICT competences for Net generation students. In P. Díaz, Kinshuk, I. Aedo, \& E. Mora (Eds.), Proceedings of the Eighth IEEE International Conference on Advanced Learning Technologies (ICALT '08) (pp. 480481). Santander, Cantabria: IEEE Computer Society. doi:10.1109/ ICALT.2008.267

*Guzdial, M., \& Soloway, E. (2002). Teaching the Nintendo generation to program. Communications of the ACM, 45(4), 17-21. doi:10.1145/505248.505261

Hamilton, D. W., \& Torraco, R. J . (2013). Integrative review of the literature on adults with limited education and skills and the implications for human resource development. Human Resource Development Review, 12(3), 308-328. doi:10.1177/ 1534484312471135

*Harel, I. (1997). Clickerati kids: Who are they? 21st Century Learning, MaMaMedia.com. Retrieved from http:// www.mamamedia.com/areas/grownups/new/21_learning/ main.html

*Helsper, E. J ., \& Eynon, R. (2010). Digital natives: Where is the evidence? British Educational Research J ournal, 36(3), 503-520. doi:10.1080/01411920902989227

*Holloway, S., \&Valentine, G. (2001). Cyberkids: Youth identities and communities in an on-line world. London: Routledge.

*Holloway, S. L., \& Valentine, G. (2003). Cyberkids: Children in the information age. London: Routledge. 
*Holmes, J . (2011). Cyberkids or divided generations? Characterising young people's internet use in the UK with generic, continuum or typological models. New Media \& Society, 11041122. doi: $10.1177 / 1461444810397649$

*Hosein, A., Ramanau, R., \&J ones, C. (2010a). Are all net generation students the same? The frequency of technology use at university. In Proceedings of the IADIS International Conference on e-Learning (pp. 340-348). Freiberg, Germany. Retrieved from http:// oro.open.ac.uk/24114/

*Hosein, A., Ramanau, R., \&J ones, C. (2010b). Learning and living technologies: A longitudinal study of first-year students' frequency and competence in the use of ICT. Learning, Media and Technology, 35(4), 403-418. doi:10.1080/17439884.2010.529913

*Howe, N., \& Strauss, W. (1991). Millennials rising: The next great generation. New York: Vintage Original.

*Howe, N., \& Strauss, W. (2000). Millennials rising: The next great generation. NewYork: Vintage Original.

*J ones, C., \& Czerniewicz, L. (2010). Describing or debunking? The net generation and digital natives. J ournal of Computer Assisted Learning, 26(5), 317-320. doi:10.1111/j.13652729.2010.00379.x

*J ones, C., Ramanau, R., Cross, S., \& Healing, G. (2010). Net generation or digital natives: Is there a distinct new generation entering university? Computers and Education, 54(3), 722-732. doi:10.1016/j.compedu.2009.09.022

*J orgensen, B. (2003). Baby boomers, generation X and generation Y? Policy implications for defence forces in the modern era. Foresight, 5(4), 41-49.

doi:10.1108/ 14636680310494753

*Kennedy, G., Dalgarno, B., Gray, K., J udd, T., Waycott, J ., Bennet, S., .. Churchward, A. (2007). The net generation are not big users of Web 2.0 technologies: Preliminary findings. In R. Atkinson, C. McBeath, A. Soong Swee Kit, \& C. Cheers (Eds.), ICT: Providing choices for learners and learning. Proceedings Ascilite 2007 (pp. 517-525). Singapore: Centre for Educational Development, Nanyang Technological University.

*Kennedy, G., Dalgarno, B., Bennett, S., J udd, T., Gray, K., \& Chang, R. (2008). Immigrants and natives: Investigating differences between staff and students' use of technology. In $\mathrm{R}$. Atkinson \& C. McBeath (Eds.), Proceedings of "Hello! Where are you in the landscape of educational technology?", the Annual Conference of the Australasian Society for Computers in Learning in Tertiary Education (ASCILITE 2008) (pp. 484- 492). 
Melbourne, Victoria, Australia: Australasian Society for Computers in Learning in Tertiary Education.

*Kennedy, G., Dalgarno, B., Bennett, S., Gray, K., Waycott, J ., Judd, T., . . Chang, R. (2009). Educating the Net Generation: A handbook of findings for practice and policy. Strawberry Hills, N.S.W.: Australian Learning and Teaching Council.

*Kennedy, G. E., J udd, T. S., Churchward, A., Gray, K., \& Krause, K. D. (2008) First year students' experiences with technology: Are they really digital natives? Australasian J ournal of Educational Technology, 24(1), 108-122.

*Kennedy, G., J udd, T., Dalgarno, B., \&Waycott, J . (2010). Beyond natives and immigrants: Exploring types of net generation students. J ournal of Computer-Assisted Learning, 26(5), 333-343. doi: 10.1111/j.1365-2729.2010.00371.x

*Kitsis, S.M. (2008). The Facebook generation: Homework as social networking. English J ournal, 98(2), 30-36.

*Koeller, M. (2012). From baby boomers to generation y millennials: Ideas on how professors might structure classes for this media conscious generation. J ournal of Higher Education Theory \& Practice, 12(1), 77- 82.

*Kolikant, Y. B. (2010). Digital natives, better learners? Students' beliefs about how the internet influenced their ability to learn. Computers in Human Behavior, 26(6), 1384-1391. doi:10.1016/j.chb.2010.04.012

*Koutropoulos, A. (2011). Digital natives: Ten years after. MERLOT J ournal of Online Learning and Teaching, 7(4), 525- 538.

*Lai, K.-W., \& Hong, K.-S. (2014). Technology use and learning characteristics of students in higher education: Do generational differences exist? British J ournal of Educational Technology, 1- 14. doi:10.1111/ bjet.12161

*Lancaster, L. C., \& Stillman, D. (2002). When generations collide: Who they are. Why they clash. How to solve the generational puzzle at work. New York: Collins Business.

*Lenhart, A., Rainie, L., \&Lewis, O. (2001). Teenage life online: The rise of instant-message generation and the internet's impact on friendship and family relationships. Washington, DC: Pew Internet \& American Life Project.

*Levin, D., \&Arafeh, S. (2002). The digital disconnect: The widening gap between Internetsavvy students and their schools. Washington DC: Pew Internet \&American Life Project. 
*Li, Y., \& Ranieri, M. (2010). Are "digital natives" really digitally competent?-A study on Chinese teenagers. British J ournal of Educational Technology, 41(6), 1029- 1042. doi:10.1111/j.1467-8535.2009.01053.x

*Littlejohn, A., Beetham, H., \& McGill, L. (2012). Learning at the digital frontier: A review of digital literacies in theory and practice. J ournal of Computer Assisted Learning, 28(6), 547-556. doi:10.1111/j.1365-2729.2011.00474.x

*Littlejohn, A., Margaryan, A., \&Vojt, G. (2010). Exploring students' use of ICT and expectations of learning methods. Electronic J ournal of E-Learning (EJ EL), 8(1), 13-20.

*Liu, F. (2010). The Internet in the everyday life-world: A comparison between high-school students in China and Norway. Comparative Education, 46(4), 527- 550. doi:10.1080/03050068.2010.519483

Luckin, R., Clark, W., Graber, R., Logan, K., Mee, A., \& Oliver, M. (2009). Do web 2.0 tools really open the door to learning? Practices, perceptions and profiles of 11-16-year-old students. Learning, Media and Technology, 34(2), 87-104. doi:10.1080/ 17439880902921949

*Maclean, G. R., \& Elwood, J . A. (2009). Digital Natives, learner perceptions and the use of ICT. In M. Thomas (Ed.), Handbook of research on Web 2.0 and second language learning (pp. 156- 179). Hershey, PA: Information Science Reference.

Malhotra, K., Ahouilihoua, N., Eshmambetova, Z., Kirungi, F., Glynn-Broderick, K., Ladd, P., . . . Palathingal, A. (2008). Making globalization work for the least developed countries. New York, NY: United Nations Development Programme.

*Margaryan, A., Littlejohn, A., \&Vojt, G. (2011). Are digital natives a myth or reality? University students' use of digital technologies. Computers \& Education, 56(2), 429-440. doi:10.1016/j.compedu.2010.09.004

*Martin, C. A., \&Tulgan, B. (2002). Managing the generational mix: From collision to collaboration. Amherst, MA: HRD Press.

*Martin, C. A., \&Tulgan, B. (2006). Managing the generation mix: From urgency to opportunity (2nd ed.). Amherst, MA: HRD Press.

*McMahon, M., \& Pospisil, R. (2005). Laptops for a digital lifestyle: Millennial students and wireless mobile technologies. In H. Goss (Ed.), Balance Fidelity, Mobility: Maintaining the Momentum? Proceedings of the 22nd ASCILITE Conference (pp. 421-431). Brisbane, Qld: Queensland University of Technology. 
*Morgan, T., \& Bullen, M. (2013). Crossing boundaries: Exploring social and academic uses of technology in Higher Education. In M. Brannon-Hamilton, S. McMinn, \& H. Moeini (Eds.), International Perspectives on Technology-Enhanced Learning IPTEL 2013 Conference Proceedings (p. 9). Vancouver, BC: The University of British Columbia: Faculty of Education.

*Nicholas, D., Rowlands, I., \& Huntington, P. (2007). Information behaviour of the researcher of the future - Executive summary. London: J ISC.

Norum, P. S. (2008). The role of time preference and credit card usage in compulsive buying behaviour. International J ournal of Consumer Studies, 32(3), 269-275. doi:10.1111/j.1470-6431.2008.00678.x

*Oblinger, D. G., \&Hawkins, B. L. (2005). The myths about students. Educause Review, 40(5), 12-13.

*Oblinger, D. G., \&Oblinger, J . L. (Eds.). (2005). Educating the net generation. Washington, DC: EDUCAUSE.

*Palfrey, J . G., \& Gasser, U. (2008). Born digital: Understanding the first generation of digital natives. NewYork: Basic Books.

*Palfrey, J ., Gasser, U., Simun, M., \& Barnes, R. F. (2009). Youth, creativity and copyright in the digital age. International J ournal of Learning \& Media, 1(2), 79-97.

doi:10.1162/ijlm.2009.0022

*Papert, S. (1993). The children's machine: Rethinking school in the age of the computer. New York: BasicBooks.

*Pedró, F. (2006). The new millennium learners: Challenging our views on ICT and learning. OECD-CERI. Retrieved from http:// www.oecd.org/ edu/ceri/38358359.pdf

*Pedró, F. (2009, September). New millennium learners in higher education: Evidence and policy implications. Paper presented at the New Millennium Learners, conference on 21st century competencies, Brussels, Belgium: OECD/CERI.

*Prensky, M. (2001a). Digital natives, digital immigrants, Part 1. On the Horizon, 9(5), 1-6. doi:10.1108/ 10748120110424816

*Prensky, M. (2001b). Digital natives, digital immigrants, Part II: Do they really think differently? On the Horizon, 9(6), 1-9.

*Prensky, M. (2006). Listen to the Natives. Educational Leadership, 63(4), 8- 13. 
*Prensky, M. (2007). How to teach with technology: Keeping both teachers and students comfortable in an era of exponential change. In Becta (Ed.), Emerging technologies for learning (Vol. 2, pp. 40-46). Coventry, UK: BECTA.

*Prensky, M. (2009). H . Sapiens digital : From digital immigrants and digital natives to digital wisdom digital wisdom. Innovate: J ournal of Online Education, 5(3). Retrieved from http:// www.wisdompage.com/ Prensky01.html

*Prensky, M. (2010). Teaching digital natives: Partnering for real learning. Thousand Oaks, CA: Corwin Press.

*Prensky, M. (2011). Digital wisdom and homo sapiens digital. In M. Thomas (Ed.), Deconstructing digital natives: Young people, technology and the new literacies (pp. 1529). New York: Routledge.

*Qayyum, A., Bullen, M., Morgan, T. \& Belfer, K. (2008, April). The digital learner at BCIT: The myth and the reality. Presentation to the Canadian Network for Innovation in Education (CNIE) Conference, Banff, Alberta, Canada.

*Ramanau, R., Hosein, A., \&J ones, C. (2010). Learning and living technologies: A longitudinal study of first-year students' expectations and experiences in the use of ICT. In L. Dirckinck-Holmfeld, V. Hodgson, C. J ones, M. de Laat, D. McConnell, \& T. Ryberg (Eds.), Proceedings of the Seventh International Conference on Networked Learning 2010. (pp. 627-634). Lancaster: Lancaster University.

*Rapetti, E. (2011). The knowledge society between "smart devices" and "digital learners": A pedagogical-anthropological reflection about the implications of dominant rhetoric in eLearning field. In L. Cantoni, P. Dillenbourg, \&D. Euler (Eds.), Proceedings of the RedConference: Rethinking Education in the Knowledge Society (pp. 236- 253). Ascona, Switzerland: Università della Svizzera italiana.

*Rapetti, E. (2012). LoDE: Learners of digital era (Doctoral dissertation). Università della Svizzera italiana. Retrieved from RERO DOC: Library Network of Western Switzerland (2012COM006).

*Rapetti, E., \& Cantoni, L. (2010a). “Digital natives” and learning with the ICTs: The "GenY @ work" research in Ticino, Switzerland". J ournal of E-Learning and Knowledge Society, 6(1), 39-49.

*Rapetti, E., \& Cantoni, L. (2010b). Exploring the added value of digital technologies and eLearning in higher education from learners' perspective: A research informed by a systematized literature review. In L. Gómez Chova, D. Martí Belenguer, \& I. Candel 
Torres (Eds.), Edulearn 10. International conference on Education and New Learning Technology (pp. 1403-1412). Barcelona, Spain: International Association of Technology, Education and Development (IATED).

*Rapetti, E., \& Cantoni, L. (2012). Reconsidering "Gen Y" \& Co: From minding the gap to overcoming it. In M. F. Paulsen \&A. Szücs (Eds.), Open Learning Generations: Closing the gap from Generation ' $Y$ " to the mature lifelong learners. Eden 2012 International Conference (p. 19). Porto: European Distance and E-Learning Network.

*Rapetti, E., \& Cantoni, L. (2013). Reconsidering “Gen Y” \& Co: From minding the gap to overcoming it [Special issue]. The European J ournal of Open, Distance and E-Learning - EURODL (Best of EDEN 2012), 1- 13. Retrieved from http:// www.edenonline.org/system/files/027_Rapetti_Cantoni_BRPA.pdf

*Rapetti, E., \& Marshall, S. (2010). Observing ICTs in learners' experiences around the world. QWERTY - Interdisciplinary J ournal of Technology, Culture and Education, 5(2), 61-88.

*Rideout, V., Foehr, U., \& Roberts, D. (2010). Generation M2: Media in the lives of 8 to 18 yearolds. Menlo Park, CA: Kaiser Family Foundation.

*Roberts, D., Foehr, U., \& Rideout, V. (2005). Generation M: Media in the lives of 8 to 18 yearolds. Menlo Park, CA: Kaiser Family Foundation.

*Romero, M., Guitert, M., Bullen, M., \& Morgan, T. (2011). Learning in digital: An approach to digital learners in the UOC scenario [Special issue]. European J ournal of Open, Distance and E-Learning, 1- 8.

*Romero, M., Guitert, M., Sangrà, A., \&Bullen, M. (2013). Do UOC students fit in the Net generation profile? An approach to their habits in ICT use. The International Review of Research in Open and Distance Learning, 14(3), 158- 181.

*Rosen, L. D. (2007). Me, MySpace and I: Parenting the net generation. Hampshire: Palgrave Macmillan.

*Rosen, L. D., Carrier, L. M., \& Cheever, N. A. (2010). Rewired: Understanding the I-Generation and the way they learn. NewYork: Palgrave Macmillan.

*Rowlands, I., Nicholas, D., Williams, P., Huntington, P., Fieldhouse, M., Gunter, B., . . Tenopir, C. (2008). The Google generation: The information behaviour of the researcher of the future. Aslib Proceedings: New Information Perspectives, 60(4), 290-310.

*Rushkoff, D. (2006). ScreenAgers: Lessons in chaos from digital kids. Cresskill, NJ : Hampton Press. 
Russell, C. L. (2005). An overview of the integrative research review. Progress in Transplantation, 15(1), 8-13.

*Salajan, F. D., Schönwetter, D. J., \& Cleghorn, B. M. (2010). Student and faculty intergenerational digital divide: Fact or fiction? Computers \& Education, 55(3), 1393-1403. doi:10.1016/j.compedu.2010.06.017

Salomon, G. (2000, J une). It's not just the tool, but the educational rationale that counts. Keynote presented at the 2000 ED-MEDIA Meeting, Montreal. Retrieved from http:// www.aace.org/conf/ edmedia/00/salomonkeynote.htm

*Sánchez, J., Salinas, A., Contreras, D., \& Meyer, E. (2011). Does the new digital generation of learners exist? A qualitative study. British J ournal of Educational Technology, 42(4), 543- 556. doi:10.1111/j.1467-8535.2010.01069.x

*Schulmeister, R. (2010). Deconstructing the net generation thesis. QWERTY - Open and Interdisciplinary J ournal of Technology, Culture and Education, 5(2), 26- 60.

*Selwyn, N. (2009). The digital native - myth and reality. Aslib Proceedings: New Information Perspectives, 61(4), 364- 379. doi:10.1108/00012530910973776

*Sharpe, R. (2010). Conceptualizing differences in learners' experiences of e-learning: A review of contextual models. Report of the Higher Education Academy LearnerDifference (HEALD) Synthesis Project. Retrieved from http:// www.heacademy.ac.uk/resources/detail/evidencenet/Conceptualizing_differ ences_in_learners_experiences_of_e-learning

*Skiba, D. J . (2010). Digital wisdom: A necessary faculty competency? Nursing Education Perspectives, 31(4), 251-253.

*Smith, E. E. (2012). The digital native debate in Higher Education: A comparative analysis of recent literature. Canadian J ournal of Learning and Technology, 38(3), 1- 18.

*Soloway, E. (1991). How the Nintendo generation learns. Communications of the ACM, 34(9), 23- 26, 96. doi:10.1145/ 114669.114717

*Stoerger, S. (2009). The digital melting pot: Bridging the digital native-immigrant divide. First Monday, 14(7). doi:10.5210/ fm.v14i7.2474

*Tapscott, D. (1998). Growing up digital: The rise of the net generation. New York: McGrawHill. 
*Tapscott, D. (2009). Grown up digital: How the net generation is changing your world. New York: McGraw Hill.

*Taylor, P., \& Keeter, S. (Eds.) (2010). Millennials: A portrait of generation next. Confident. Connected. Open to Change. Washington, DC: Pew Research Center.

*Thinyane, H. (2010). Are digital natives a world-wide phenomenon? An investigation into South African first year students' use and experience with technology. Computers \& Education, 55(1), 406-414. doi:10.1016/j.compedu.2010.02.005

*Thirunarayanan, M.O., Lezcano, H., McKee, M., \& Roque, G. (2011, February). “Digital nerds” and "digital normal": Not "digital natives" and "digital immigrants". International J ournal of Instructional Technology and Distance Learning, 8(2). Retrieved from http:// www.itdl.org/J ournal/Feb_11/article03.htm

*Thomas, M. (2011). Deconstructing digital natives: Young people, technology, and the new literacies. New York: Routledge.

Torraco, R. J . (2005). Writing integrative literature reviews: Guidelines and examples. Human Resource Development Review, 4(3), 356-367. doi:10.1177/ 1534484305278283

*Twenge, J . M. (2006). Generation me: Why today's young Americans are more confident, assertive, entitled--and more miserable than ever before. NewYork: Free Press.

*Twenge, J . (2009). Generational changes and their impact in the classroom: Teaching Generation Me. Medical Education, 43(5), 398-405. doi:10.1111/j.13652923.2009.03310.x.

*Valentine, G., \& Holloway, S. L. (2002). Cyberkids? Exploring children's identities and social networks in on-line and off-line worlds. Annals of the Association of American Geographers, 92(2), 302-319. doi:10.1111/ 1467-8306.00292

*Veen, W. (2003). A new force for change: Homo zappiens. The Learning Citizen, 7, 5-7.

*Veen, W. (2007). Homo Zappiens and the Need for New Education Systems. Paper presented at OECD seminar on Digital Natives and Education. Florence, Italy: OECD-CERI. Retrieved from http:// www.oecd.org/ edu/ ceri/ 38360892.pdf

*Veen, W. \& Vrakking, B. (2006). Homo zappiens, growing up in a digital age. London: Network Continuum Education. 
Virkus, S. (2008). Use of Web 2.0 technologies in LIS education: Experiences at Tallinn University, Estonia. Program: Electronic library and information systems, 42(3), 262274. doi:10.1108/00330330810892677

*Weiler, A. (2005). Information-seeking behavior in generation Y students: Motivation, critical thinking, and learning theory. The J ournal of Academic Librarianship, 31(1), 46-53.

*Weinberger, D. (2008, J anuary). Digital natives, immigrants and others. KMWorld, 17(1). Retrieved from http:/ / www.kmworld.com/Articles/News/News-Analysis/ Digitalnatives-immigrants-and-others-40494.aspx

*White, D., \& Le Cornu, A. (2011). Visitors and residents: A new typology for online engagement. First Monday: Peer-Reviewed J ournal on the Internet, 16(9). doi:10.5210/ fm.v16i9.3171

Whittemore, R., \& Knafl, K. (2005). The integrative review: Updated methodology. J ournal of Advanced Nursing, 52(5), 546-553.

*Zemke, R., Raines, C., \& Filipczak, B. (2000). Generations at work: Managing the clash of Veterans, Boomers, Xers, and Nexters in your workplace. New York: AMACOM.

(C) Gallardo-Echenique, Marqués-Molías, Bullen, and Strijbos

\section{Athabasca University}

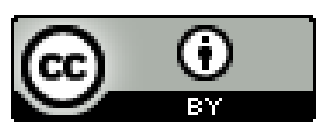

